\title{
IMPLEMENTATION OF GUIDED INQUIRY LEARNING MODEL TO IMPROVE STUDENT SCIENTIFIC LITERACY ON FACTORS AFFECTING RATE OF REACTION MATERIALS
}

\author{
Era Melania and Bertha Yonata* \\ Chemistry Education Study Program, Faculty Mathematics and Natural Science, State University of Surabaya, \\ Surabaya, Indonesia \\ *Email: berthayonata@unesa.ac.id
}

Accepted: January 13, 2022. Approved: January 14, 2022. Published: January 16, 2022

\begin{abstract}
The research aimed to describe the guided inquiry learning model's effectiveness in improving students' scientific literacy ability. The effectiveness is assessed based on: 1) the implementation of the guided inquiry learning model and 2) students' chemistry learning outcomes on factors affecting the rate of reaction material after implementing the guided inquiry learning model. This research is quantitative descriptive research. It was conducted in an experimental class. The research design used is one group pretest-posttest design. In this research, there were 23 students of class XI MIA 3 SMA Muhammadiyah 10 GKB Gresik in the academic year of 2021/2022 as respondents. For the data collecting, this research uses an observation sheet on implementing a guided inquiry learning model and test sheets for students' scientific literacy on the factors that affect reaction rates material. The data model of implementation percentage that appears at meetings 1 to 3 from the preliminary to the closing activities is $100 \%$ (very good). The pretest result shows that 20 students have not achieved the minimum completeness criteria based on three scientific competencies: 1) explaining phenomena scientifically, 2) evaluating and designing scientific experiments, and 3) interpreting data and evidence scientifically. The posttest results show that students' scientific literacy is increased after implementing guided inquiry in the learning process and is $100 \%$ classically completed. The Wilcoxon test result shows that the average pretest score and posttest scores in students' scientific literacy ability are significantly different in the realm of knowledge and skills with the value of Asymp. Sig. (2-tailed) $=0.000$.
\end{abstract}

Keywords: Guided Inquiry, Scientific Literacy, Factors Affecting Rate of Reaction

\section{INTRODUCTION}

Chemistry is classified into the family of natural sciences. Chemistry is closely related to everyday life. Chemistry learning carried out in schools involves skills and reasoning involving the interaction between students and the environment. In learning chemistry, one must pay attention to the characteristics of chemistry as a natural science which includes chemistry as a process and product. So that learning chemistry is to meet the demands of learning at school and solve various everyday problems.

Chemistry learning is one of the lessons in high school (SMA) that requires laboratory work. According to the pre-research data results conducted at SMA Muhammadiyah 10 GKB Gresik. It shows that the chemistry learning process is often applied with a percentage of $80 \%$, giving project assignments with a percentage of $8 \%$, and lab works with a percentage of $12 \%$ so that it can be said practically. The delivery of material is still mostly done using the lecture method.

One of the materials from chemistry subjects is the rate of reaction in which students are required to understand the material and apply it in everyday life. The rate of reaction material requires the ability to memorize and calculate and requires experimental activities to prove the factors affecting the rate of reaction.

Based on the pre-research conducted at SMA Muhammadiyah 10 GKB Gresik, 25 students showed that $92 \%$ of students considered chemistry difficult. Based on an interview with chemistry teachers, learning outcomes in the reaction rate material are still relatively low. The students ignore the material explained by the teacher during learning, the teacher's lack of creativity in creating fun learning, and the lack of student involvement during the learning process. The important component in the meaningfulness of a learning activity is the involvement of students. When the students are involved in learning activities, meaningful learning will be created. Meaningful learning is associating new information with relevant information that has previously been built in a person's cognitive structure so that when a person is given a unique learning situation. He can relate the new information to the concepts that have been built [1]. When students get meaningful lessons, the information obtained will take longer to remember.

One way to create meaningful chemistry learning is to create lessons that reveal everyday phenomena or problems. In overcoming these phenomena or problems, scientific information is needed that can be obtained through scientific literacy. Scientific literacy emphasizes thinking and acting skills. Ability in scientific literacy is necessary for students to understand the environment, health, and technology. Therefore, to improve education quality in Indonesia to be able to compete in the $21^{\text {st }}$ century, the level of scientific 
literacy is important to know to achieve a better literacy level [2]

Scientific literacy can respond and solve scientific issues with scientific ideas. Students who have mastered scientific literacy will always want to be involved in all science and technology problems that require competence to explain a phenomenon scientifically, evaluate and design a scientific investigation, and interpret data and evidence scientifically [3]. Based on the results of PISA (Program for International Student Assessment), the scientific literacy score of Indonesian students was 383 in 2009 and ranked $60^{\text {th }}$ out of 65 countries. PISA resulted in 2012, the scientific literacy score of students in Indonesia was 382 and was in the $64^{\text {th }}$ position out of 65 countries. In 2015, Indonesia scored 403 and was ranked 62 out of 70 countries [4]. The 2018 PISA scientific literacy results in Indonesia are on the order of 70 out of 78 countries and had a score of 396 [5]. These results indicate that Indonesia is still below the average international literacy score.

Reflecting on what has been described, it can be concluded that a learning model is needed to increase students' scientific literacy ability level to create meaningful learning. One of the learning models that can be implemented to improve the students' scientific literacy ability is the inquirybased learning model.

The inquiry-based learning model is a learning model that develops learning steps to build students' thinking [6]. The implementation of guided inquiry can help students to create their concepts. Students will use their prior knowledge and relate the new information they get in the unique learning situation and process. The steps in this learning model also emphasize students work on their initiative, addressing everything objectively and honestly. In addition, inquiry-based learning also emphasizes students' abilities in designing scientific methods such as formulating problems and hypotheses [7].

Along with the strength of guided inquiry, this learning model also has weaknesses. The shortcoming of the inquiry learning model is that it requires a change in students' learning habits who receive information from the teacher to become independent learning by seeking and processing data on their own. Teachers are required to change the teaching method, which is generally as a presenter of information to become a facilitator, involves the provision of adequate learning resources and facilities that are not always available and not efficient for teaching large numbers of students [8]. In this model, the teacher's central role is to facilitate the inquiry process by setting goals, identifying appropriate problems for investigation, and helping students reflect on their ways and thought processes. This model also provides opportunities for students to find or solve a problem by carrying out scientific activities.

The learning model that affects increasing students' scientific literacy is inquiry-based learning. Inquiry-based learning will increase the possibility of students having high scientific literacy ability and positively impact understanding and experience of science [9]. Therefore, applying the guided inquiry learning model can improve students' scientific literacy skills [10]-[13].

Based on this description, it is essential to apply a guided inquiry learning model to improve students' ability in scientific literacy on the material Factors Affecting the Rate of Reaction.

\section{RESEARCH METHOD}

The research type is quantitative descriptive research. The research design in this study was one group pretest-posttest research design. Students were given a treatment which was an implementation of inquiry-based learning. This research was conducted in one study group without a comparison group. Data were obtained through two methods: observation and test. Statement of the learning model implementation is made during the learning process. This research targets students of class XI MIA 3 at SMA Muhammadiyah $10 \mathrm{GKB}$ Gresik. A pretest and posttest will be carried out in this study after being given treatment. The test is carried out to obtain quantitative data due to students' chemistry learning.

\section{Description:}

$$
\mathrm{O}_{1}-\mathrm{X}-\mathrm{O}_{2}
$$

$\mathrm{O}_{1} \quad$ : Pretest score result

$\mathrm{X}$ : : The treatment of the implementation of guided inquiry

$\mathrm{O}_{2} \quad$ : Posttest result

In implementing learning, it is necessary to have a learning instrument. The learning instrument used is the syllabus. The syllabus was used in the learning process, using a scientific approach. The other instruments were the Learning Implementation Plan (RPP) and student worksheets (LKPD). All the learning instrument in this research has been reviewed and validated by the lecturer of Universitas Negeri Surabaya. The LKPD used is an inquirybased LKPD. The LKPD used in this study is an adaptation of the LKPD developed in research. The effectiveness of the existing LKPD is categorized very high, the validity classified as very valid, and the practicality of the LKPD is efficient [14].

Several research instruments were used to evaluate the guided inquiry learning model's effectiveness in improving students' scientific literacy ability. The research instrument was an observation sheet on implementing the learning model and a pretest and posttest sheet for students' scientific literacy abilities. The application of the 
syntax of the learning model is assessed based on the fulfillment of learning activities or syntax from introduction to closing. The learning process was carried out in three meetings, and observations were carried out three times. The observers consisted of one chemistry teacher at SMA Muhammadiyah 10 GKB Gresik and two chemistry education students.

The data on the teacher's competence to apply the inquiry learning model was analyzed using the percentage interval described on criteria. The learning process is categorized as very good if the percentage of syntax implementation obtained in all aspects is $81 \%-100 \%$. On the implementation observation sheet, there are scores of 0 to 4 in each aspect or step of learning, and the percentage is calculated using the following formula:

$\%$ Implementation $=\underline{\text { Score obtained }} \times 100 \%$ Maximal Score

The percentage of implementation obtained can be described based on Table 1

Table 1. Implementation Criteria

\begin{tabular}{cc}
\hline Percentage $(\%)$ & Criteria \\
\hline $0-20$ & Very Less \\
$21-40$ & Less \\
$41-60$ & Enough \\
$61-80$ & Good \\
$81-100$ & Very Good \\
\hline
\end{tabular}

Evaluation of students' competence in scientific literacy was done through the pretest and posttest scores. Scientific literacy ability can be analyzed through the Wilcoxon test and classical completeness by computing individual completeness with a score above Minimum Completeness Criteria (KKM $\geq 77)$. These are the minimum criteria required for students to achieve the completeness determined by the school in chemistry subjects for grade 11 for specialization classes in mathematics and natural sciences. Classical completeness can be determined using the equation:

$\%$ Classical Completeness $=\underline{\Sigma \mathrm{M}} \times 100 \%$

Description:

$\Sigma \mathrm{M}$ : The number of students who achieve completeness

$\Sigma \mathrm{N} \quad$ : The number of all students

A class or group can be classically complete if the members of the course or group achieve completeness of $85 \%$ or more [16].

The pretest score and posttest scores obtained were analyzed by comparing the mean of the two data. The test was in the realm of knowledge and skills. The analysis was carried out using the Wilcoxon test. The Wilcoxon test is a nonparametric test used if the data obtained are not normally distributed or an alternative to the paired $\mathrm{t}$ test if the data are not normally distributed. Wilcoxon is a non-parametric statistical technique used to test whether there is a difference in one paired variable, interval, or ratio caused by one independent variable that is nominal or ordinal [17].

\section{RESULT AND DISCUSSION}

The outcomes from this research are observational data on teachers' ability to implement the learning model and the result of students' scientific literacy ability tests as pretest and posttest.

\section{Implementation of Learning Model}

The purpose of observing the application of the guided inquiry is to observe the teacher apply the learning model to the teaching and learning process in the classroom according to the learning syntax and assess whether the teacher has trained scientific literacy ability in learning activities. The teacher's application of the guided inquiry from the introduction to closing activities was categorized as very good. The following is the data from the observation of guided inquiry implementation obtained at the first meeting in Table 2.

Table 2. Percentage of Learning Model Implementation

\begin{tabular}{ccc}
\hline $\begin{array}{c}\text { The } \\
\text { meetings }\end{array}$ & $\begin{array}{c}\text { Learning } \\
\text { activity }\end{array}$ & $\begin{array}{c}\text { Mode of the } \\
\text { implementation } \\
\text { percentage }\end{array}$ \\
\hline \multirow{2}{*}{$1^{\text {st }}$ meeting } & Preliminary & $100 \%$ \\
& Core & $100 \%$ \\
& Closing & $100 \%$ \\
\hline \multirow{2}{*}{$2^{\text {nd }}$} & Preliminary & $100 \%$ \\
meeting & Core & $100 \%$ \\
& Closing & $100 \%$ \\
\hline \multirow{2}{*}{$3^{\text {rd }}$ meeting } & Preliminary & $100 \%$ \\
& Core & $100 \%$ \\
& Closing & $100 \%$ \\
\hline
\end{tabular}

Learning model implementation carried out by the teacher is categorized as very good. All aspects from preliminary to closing activities were carried out with a mode percentage of $100 \%$. It can be concluded that from $1^{\text {st }}$ to $3^{\text {rd }}$ meetings, the teacher has carried out learning according to the syntax of the guided inquiry to train scientific literacy ability.

In studying chemistry, students need to be given learning by conducting scientific experiments to apply scientific literacy. The inquiry learning model is considered capable of training scientific literacy to help solve simple everyday problems scientifically. The syntax of the guided inquiry supports students' ability in scientific literacy. 


\section{Scientific Literacy Ability}

Evaluating the scientific literacy ability was determined using the pretest and posttest methods. Pretest was conducted before the learning process before the students received the material on the factors affecting the rate of reaction to determine students' initial abilities. Then the students were given treatment by implementing guided inquiry on the material factors affecting the rate of reaction. At the end of the lesson, students were given a posttest to find out the increase in scientific literacy ability.

The pretest results show that the students' scientific literacy abilities have not been completed. Twenty students scored below the KKM, and three scored above the KKM. The posttest results showed that all students scored above the KKM with classical completeness of $100 \%$.

Students' mastery of concepts significantly increased after applying the guided inquiry. The learning syntax made students more actively involved in the learning activities. The teachers' role is only as a motivator and facilitator. Students find their concepts in the guided inquiry phase when conducting scientific investigations. Inquiry-based learning, students will think of ways to find and process new information to relate it to new learning situations [18].

In improving scientific literacy and understanding of science, student involvement is one factor that needs to be considered [19]. The guided inquiry emphasizes hands-on learning experiences through investigation activities, building concepts, and then applying the concepts that have been obtained in everyday life [20]. It will affect increasing scientific literacy because students will solve problems with their scientific knowledge.

Scientific literacy that will be improved in this research is scientific competence. Conclusion: There is the ability to explain phenomena scientifically, evaluate and design or plan a scientific investigation, and interpret data and evidence scientifically. The test instrument consists of ten multiple-choice (objective) questions and ten essay questions with details of 13 questions in the realm of knowledge and seven questions in the realm of skills. The recapitulation of students' scores in the realm of knowledge and abilities is presented in Figure 1.

The pretest and posttest questions contain three indicators of scientific competence, which will be tested to see the increase experienced by students. The first indicator explains the scientific phenomena tested on questions number 1 until 4 from multiple choice questions, number 1 from essay questions in the realm of knowledge, and numbers 2 and 4 in essay questions in skills. The second indicator is evaluating and designing scientific phenomena tested on questions number 5,6,7, and 10 from multiple choice questions, number 2 from essay questions in the realm of knowledge, and numbers
1,3 , and 6 in essay questions in the realm of skills. The third indicator is interpreting data and scientifically evidence tested on questions number 9 and 8 from multiple choice questions, number 3 from essay questions in the realm of knowledge, and number 5 and 7 from essays in the realm of skills.

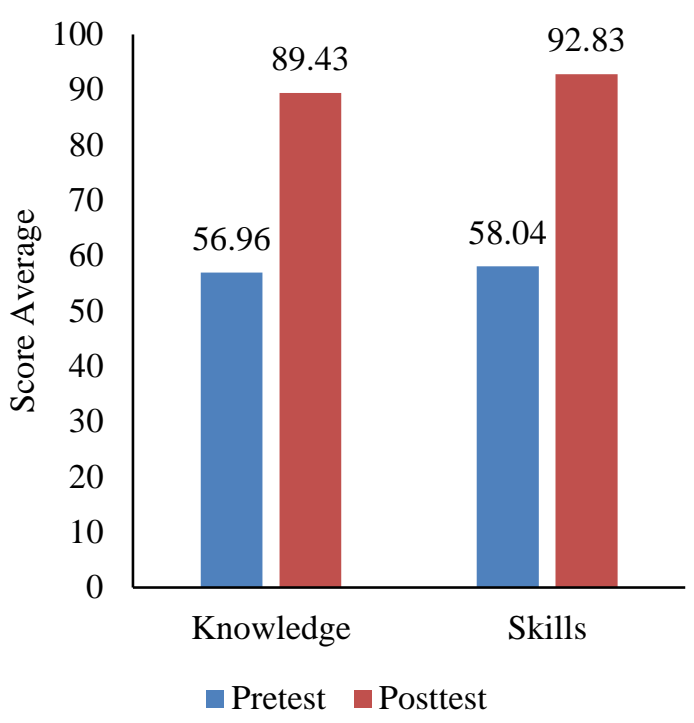

Figure 1. Average of student test scores

In the first indicator, the pretest results show that students' scientific literacy ability has not yet reached completeness. On this indicator, 19 students have not achieved completeness, and as many as 4 students can achieve completeness on indicators explaining scientific phenomena. The results of the posttest, there is an increase experienced by students. Namely, all students have achieved completeness on indicators explaining scientific phenomena.

In the second indicator, the pretest results show that students have not achieved completeness with details. 2 students can achieve completeness and 21 students have not. In the results of the posttest, there was an increase experienced by students. Namely, all students had been able to achieve completeness on the indicators of evaluating and designing scientific investigation.

In the third indicator, the pretest results show that students have not achieved completeness as a whole with details 3 students have completed completeness and 20 students have not achieved completeness. The results of the posttest showed that there was an increase experienced by students, with the results showing that all students were able to achieve completeness on indicators of interpreting data and evidence scientifically.

After getting pretest and posttest results of scientific literacy ability, the data was analyzed. The first analysis is classical completeness. After applying the guided inquiry learning model, as many as 23 students or $100 \%$, classical completeness was 
obtained. Data analysis was also carried out using the Wilcoxon test to determine whether there is a significant difference between the pretest and posttest results. IBM SPSS Statistics 25 is used to help analyze the Wilcoxon test. Asymp determines the conclusion. Sig. (2-tailed). If Asymp. Sig. (2tailed) $\leq 0.05$, then there is a difference in the mean pretest and posttest results.

Based on the analysis of the Wilcoxon test, the average pretest score and posttest scores of students' scientific literacy were significantly different. Asymp. Sig. (2-tailed) a value obtained is 0.000. The Asymp. Sig (2-tailed) is smaller than 0.05 . The conclusion is obtained that there is a significant difference in knowledge and skills. The summary of statistical analysis is shown in the following table below.

Table 3. Wilcoxon Test Result in the Realm of Knowledge

\begin{tabular}{lr}
\hline $\mathrm{Z}$ & $-4.205^{\mathrm{b}}$ \\
Asymp. Sig. (2-tailed) & .000 \\
\hline
\end{tabular}

Table 4. Wilcoxon Test Result in the Realm of Skills

\begin{tabular}{lr}
\hline $\mathrm{Z}$ & $-4.200^{\mathrm{b}}$ \\
Asymp. Sig. (2-tailed) & .000 \\
\hline
\end{tabular}

\section{CONCLUSION}

According to the analysis, it can conclude that implementation is said to be very good based on the data model of the percentage of learning model implementation in the preliminary to closing activities from $1^{\text {st }}$ to $3^{\text {rd }}$ meetings is $100 \%$. Guided inquiry can significantly improve students' scientific literacy competence based on classical completeness, which reaches $100 \%$, and Wilcoxon test results show differences in scientific literacy in the realm of knowledge and skills with Asymp. Sig. (2-tailed) value $=0.000$.

\section{REFERENCES}

[1] Dahar, R. W. (2011). Teori Belajar dan Pembelajaran. Erlangga.

[2] Pratiwi, S. N., Cari, C., \& Aminah, N. S. (2019). Pembelajaran IPA Abad 21 dengan Literasi Sains Siswa. Jurnal Materi Dan Pembelajaran Fisika, 9, 34-42.

[3] OECD. (2019). PISA 2018 Assessment and Analytical Framework.

[4] OECD. (2017). PISA 2015 Assessment and Analytical Framework: Science, Reading, Mathematics, Financial Literacy and Collaborative Problem Solving.

[5] OECD. (2019). PISA 2018: Insights and Interpretations. OECD Publisher.
[6] Arends, R. I. (2012). Learning to Teach. McGraw-Hill.

[7] Roestiyah. (2012). Strategi Belajar Mengajar. Rineka Cipta.

[8] Simbolon, D. H. (2015). Pengaruh Model Pembelajaran Inkuiri Terbimbing Berbasis Eksperimen Riil dan Laboratorium Virtual terhadap Hasil Belajar Fisika Siswa. Jurnal Pendidikan Dan Kebudayaan, 21, 299-315.

[9] McConney, A., Oliver, M. C., Amanda, W. M., Schibeci, R., \& Maor, D. (2014). Inquiry, Engagement, and Literacy in Science: A Retrospective, Cross-National Analysis Using PISA 2006. Science Education, 963-980.

[10] Muliastrini, N. K. E., Nyoman, D., \& Rasben, D. G. (2019). Pengaruh Model Pembelajaran Inkuiri dengan Teknik Scaffolding Terhadap Kemampuan Literasi Sains dan Prestasi Belajar IPA. Jurnal Ilmiah Sekolah Dasar, 3(3), 254-262.

[11] Rewalino, Y. I., Supriyatman, \& Kade, A. (2020). Pengaruh Model Pembelajaran Inkuiri Terbimbing Terhadap Kemampuan Literasi Sains Siswa. Jurnal Pendidikan Fisika Tadulako, 8(3), 125-128.

[12] Anggraeni, A. Y., Wardani, S., \& Hidayah, A. N. (2020). No Title. Jurnal Inovasi Pendidikan Kimia, 14(1), 2512 - 2523.

[13] Yessi, M. (2019). Pembelajaran Berbasis Guided InquiryUntuk Meningkatkan Literasi Sains Siswa Kelas X MIPAPada Materi Larutan Elektrolit Dan Nonelektrolit. Jurnal Ilmiah Kanderang Tingang, 10(1), 27-37.

[14] Ain, Q., \& Mitarlis. (2020). Pengembangan LKPD Berorientasi Inkuiri Terbimbing untuk Meningkatkan Literasi Sains pada Materi Faktor-faktor yang Mempengaruhi Laju Reaksi. UNESA Journal of Chemical Education, 9, 397-406.

[15] Riduwan. (2015). Skala Pengukuran Variabel-Variabel Pendidikan. Alfabeta.

[16] Agustini, R., Nasrudin, H., Azizah, U., \& Muchlis. (2016). Asesmen. Absolute Media.

[17] Suseno, M. (2012). Statistika: Teori dan Aplikasi untuk Penelitian Ilmu Sosial dan Humaniora. Ash-Shaff.

[18] Wardani, S., Lindawati, L., \& Kusuma, S. B. (2017). The Development of Inquiry By Using Android-System-Based Chemistry Board Game to Improve Learning Outcome and Critical Thinking Ability. Jurnal Pendidikan IPA Indonesia, 6(2), 196-205.

[19] Cahyana, U., Kadir, A., \& Gherardini, M. (2017). Relasi Kemampuan Berpikir Kritis dalam Kemampuan Literasi Sains pada Siswa Kelas IV Sekolah Dasar. Sekolah Dasar, 1, 1422. 
J. Pijar MIPA, Vol. 17 No.1, January 2022: 51-56

[20] Puspitasari, R. D., Mustaji, M., \& Rusmawati, R. D. (2019). Model Pembelajaran Inkuiri Terbimbing Berpengaruh terhadap Pemahaman dan Penemuan Konsep dalam Pembelajaran PPKn. Jurnal Imiah Pendidikan Dan Pembelajaran, 3(1), 96-107. 